\title{
Surf-ridingに適した条件の整理と前原海岸に おけるsurf spotの変遷調査 \\ OPTIMUM CONDITIONS FOR SURF-RIDING AND INVESTIGATION OF DISAPPEARANCE OF PAST SURF SPOT AT MAEBARA BEACH
}

\author{
${\text { 渡辺宗介 }{ }^{1} \cdot \text { 清野聡子 }^{2} \cdot \text { 宇多高明 }{ }^{3} \cdot \text { 芹沢真澄 } 4 \text {. 三波俊郎 }}^{5}$. \\ 古池 鋼 5 \\ Shu-suke WATANABE, Satoquo SEINO, Takaaki UDA, Masumi SERIZAWA, Toshiro SAN-NAMI \\ and Kou FURUIKE \\ 1 学生会員 東京大学大学院総合文化研究科（T 153-8902 東京都目黒区駒場 3-8-1） \\ 2 正会員 農修 東京大学大学院総合文化研究科広域システム科学科助手（同上） \\ 3 正会員 工博 建設省土木研究所河川部長（干 305-0804 茨城県つくば市旭 1) \\ 4 正会員 海岸研究室（有）（广 160-0011 東京都新宿区若葉 1-22 ローヤル若葉 208 号） \\ 5 海岸研究室（有）(同上)
}

\begin{abstract}
Optimum conditions for surf-riding was investigated. They are given by not only wave characteristics and sea bottom slope,but also wind condition determining roughness of sea surface.Disappearance of past famous surf spot due to the construction of coastal structures was investigated on the Maebara beach in Kamogawa City in Chiba Prefecture by the comparison of past aerial photographs before and after the construction of structures. Surf spot can be recognized by existence of the triangular-shape surf zone as given by the previous study.
\end{abstract}

Key words: Surf-riding, surf spot, optimum conditions, aerial photograph

\section{1. まえがき}

近年,多くの若者達がsurf-ridingを楽しんでおり,そ れが地域の発展に結びつく例も増加しつつある.米国や オーストラリアなどではそれが当然のこととして社会 的に受け入れられているが,わが国ではそ机に比べると 意識レベルが低いのが現状である. 厳しさを要求される 海洋スポーツとしてのsurf-riding の発展は大事なこと であるが，それにはsurf-ridingについての十分な理解 が必要である. Surf-ridingに関する既往の研究として, Walker et al. ${ }^{1)}$ は, peel velocity（波頂がチューブを形 成しながら横に移動する速度）を, 砕波波高, peel angle (砕波点における砕波角)の関係において, サーフィン技 術を上，中，初級に判別する図を提案し，研波波高が高 いほどpeel velocityが速くなり，それにともなってサー フィンに要求される技術レベルが高くなることを示し た. 吉田ら ${ }^{2)}$ は，良好なサーフ・ポイントである海部川 河口の海底地形に着目し, 河口テラスがサーフィンのた めの海岸構造物としてWalkerらが提案しているデル夕 型リーフと酷似し, 比較的静穏な波浪条件でもサーフィ
ンに適する砕波が形成されることを確認した．また，中 野ら ${ }^{3 ）}$ 4）は，デルタ型人工リーフの水理模型実験と緩 勾配方程式に基づく波浪の数值計算を行い, 人エリーフ 周辺の波高分布について比較した。一方，石川・酒匂 ${ }^{5)}$ は, surf-ridingの利用者レベルに応じた砕波波高をア ンケート調査より求め, Walker et al. ${ }^{1)}$ の研究結果と 比較し, long, short, body boardの順に可能砕波波高 は低下すること, また初心者は波高が低い条件でのみ可 能であるのに対し, 上級者はより高い波高を好むことを 明らかにした．海岸構造物とsurf-ridingに関する研究 としては，上述の中野ら ${ }^{3 ）} 4 ）$ による河口テラスをヒン トとした人工リーフに関する研究が最初である. 一方, 筆者ら ${ }^{6)}$ は, 防波堤など波の遮蔽構造物周辺での波浪場 とsurf-ridingの関係について九十九里浜の片貝漁港周 辺を対象として研究し, 片貝漁港という人工構造物が, その周辺の海岸地形や波などの自然条件を変化させ,防 波堤の建設によってsur-fridingに適したsurf spotが 形成されたことを空中写真の判読法によって明らかに した. 本研究は, これに続くものであり, 実際のsurfer でないとわかりにくい各種条件をまず整理した上で, 
surf spotとして混たされるべき自然条件を㺫らかにす る.さらに前報 ${ }^{6)}$ で述べた, 空中写真判読によるsurf spot調查手法を, 新たに千葉県鴨川市の前原海岸に適用 し, surf spotの変遷調查を行う。

\section{Surf-riding の特性}

\section{（1）Surf-ridingまでになされる一連の行動}

Surf-ridingは研波点付近でしか行うことができない ので, surferはまずボードの上に腹這いに乗り, 手で水 をかきながら (paddling), 砕波点付近まで行かなけれ ばならない，碀波点より岸側では伜波のエネルギーに よって岸に押し戻されるため, 奏際には碀波線より少し 沖までいく．このように沖に向かって paddlingにより 砕波線を越えることをgetting-outという. 写真一1の左 下に見えるsurfer 2 人 (矢印) はgetting-out中である. Getting-outが完了したらsurf boardにまたがって座 り, surf-ridingに適した波が来るのを待つ.この状態を 波待ちと言う。写真一1の左上（破線内）には，波待ちを している surfer を見ることができる. 波に乗るには, surfer 自身の動きを波のスピードに合わせなければな らないが, そのためにはpaddlingだけでは不十分で, 砕 波のエネルギーも利用しなければならない.このことが 砕波点付近でしか surf-ridingを行えない理由の一つで ある.したがって, surf-ridingに適した波が沖に見えた ら, surferは砕波点を予測して碀波前にそこまで移動し なければならない。そして波が近づいてきたら岸に向 かって paddling を開始し, 砕波のエネルギーも使って 一気に波の波速に合わせる. 波の波速に合わせると, 波 の力でsurf boardが走り出すので, その瞬間に立ち上が る. 写真-2のsurfer Aは立ち上がる瞬間である.このよ うに波の波速に合わせて立ち上がるまでの一連の動作 をtake-offという. Take-offをして立ち上がった後は, 波の砕波速度と砕波方向に合わせて波の斜面を滑って いく（写真-3，4）. Surferが波の斜面を滑っていく際 には, 水面とsurf boardの間に摩擦力が働く.そのため, surfer がバランスを保てるだけのスピードを得るには, ある程度波の波形勾配が大きくなくてはならない.そし

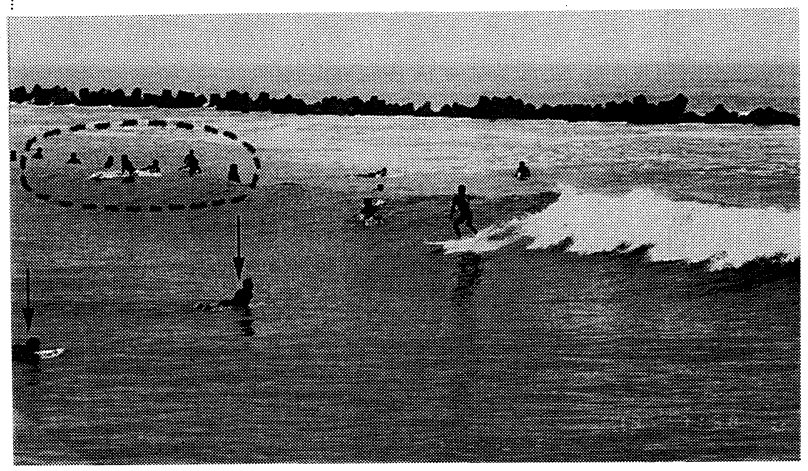

写真 -1 Getting-out 中の surfer (千葉県一の宮海岸;1998 年 7 月 19 日撮影)
て波䚲公配が鼠も大きくなるのが湖波点である.これも surf-riding が碎波点付近でしか行えない理由の一つで ある.

1波に乗れるsurferは基本的に1人であり,「波のpeak に近いところからtake-offしたsurferが優先される」と いうsurferの間でのルールがある.ここに, peakとは図 -1に示すように, 波が最初に崩れる点を指す. 写真-2に おいては, peakに近いsurfer Aに優先権があるので、 surfer Bは途中でtake-offをやめてsurfer Aに波を 譲っている. また，一般に地元のsurfer (local surfer) が，都心などから来たsurfer（visiter surfer）より優先

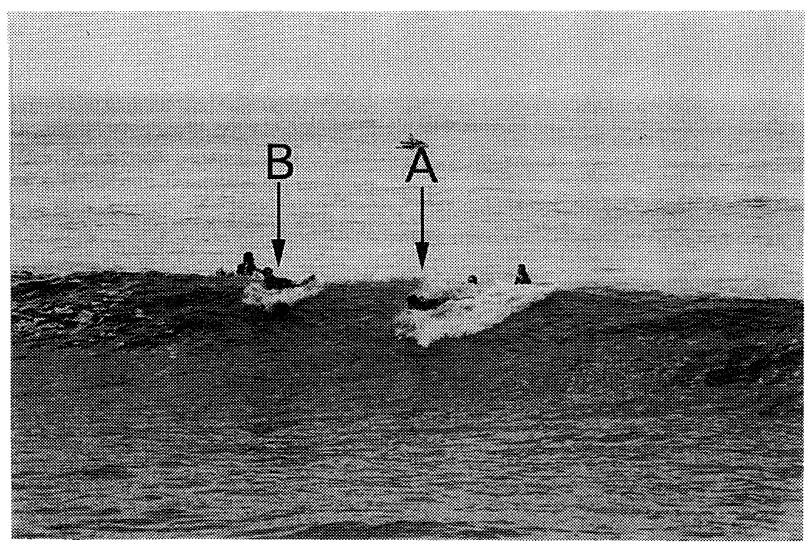

写真-2 Take-off 中の surfer と波を讓る surfer (千葉県一の宮海岸;1998 年 7 月 19 日撮影)

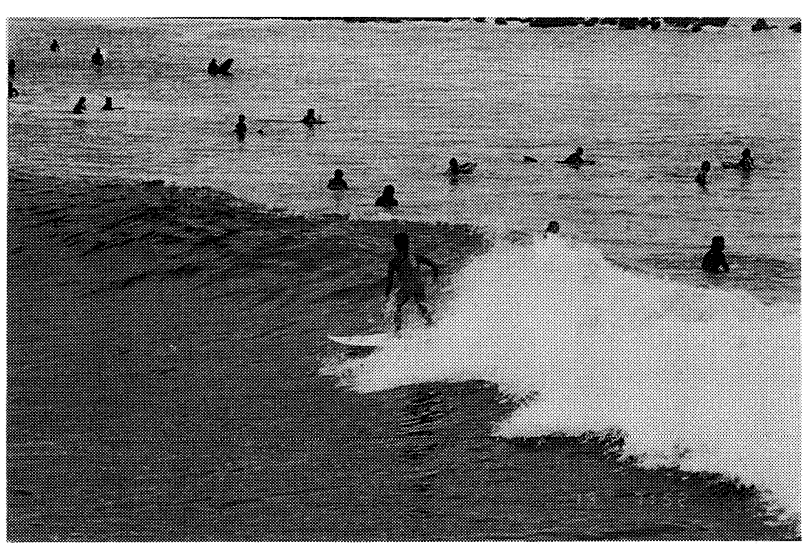

写真 -3 波の斜面を滑る surfer （千葉県一の宮海岸;1998 年 7 月 19 日撮影）

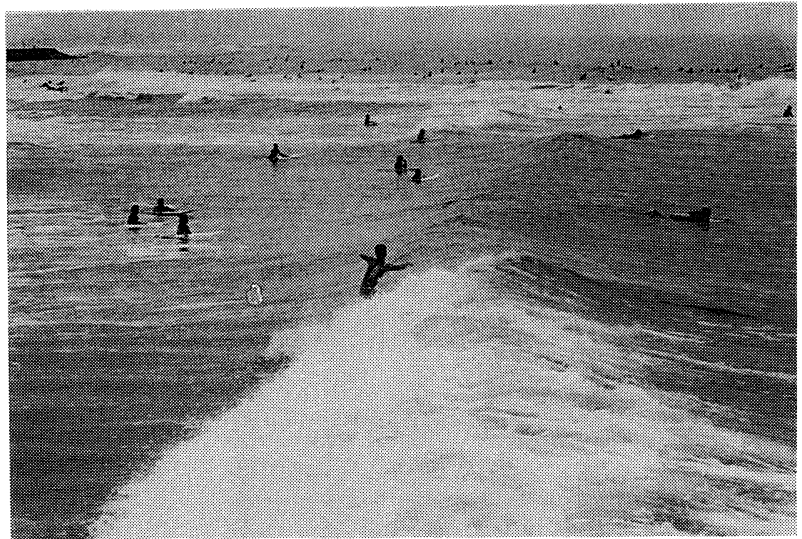

写真 -4 波の斜面を滑る surfer （千葉県一の宮海岸;1998 年 7 月 19 日撮影） 


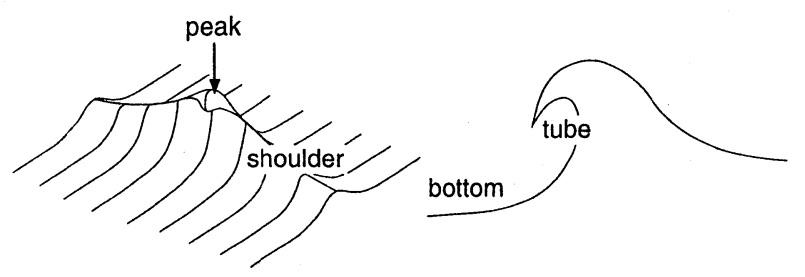

図 -1 波形の名称

され，その度合いはsurf spotによって異なる。

「1波に乗れるsurferは1人」というルールのため, 岬の 先端など，砕波点がほぼ一箇所で固定されている surf spotでは，実際にsurf-ridingできるsurferの人数には 限りがある.このため, 人工的にsurf spotを形成しよう とするときには, 利用できる人数に限りがあることに留 意する必要がある.

\section{(2) Surf boardの形状}

昔は, surf boardは木製であったが，現在ではほとん どが合成樹脂製である．大きさと形からおおまかに long board とshort boardに大別される. Long board は長さが約 $3 \mathrm{~m}$ で, 先端が丸みを帯びているのに対し, short boardは長さが約 $2 m$ で, 先端が尖っているもの が多い. また, long boardの厚みはshort boardに比較 して2〜3cm大きい. Long boardは大きく厚く, した がって大きな浮力が働くので, paddling のスピードが 速い. しかもboardが長いため, 碀波のエネルギーをあ まり利用しなくても take-offが可能である.このため, 砕波前のうねりに近い状態からでも take-off が可能で ある（図-2）。しかし，その大きさのために小さな動き には適さないので, 波形勾配の小さなゆったりと崩れて いく波が好まれる. 一方, short board は小さく薄く paddling のスピードが遅いので, 砕波のエネルギーを 利用しなければtake-offできない（図-2). しかし小さ くて操作しゃすいので, 波形勾配が大きく, 速く崩れる 波にも対応しやすい.

以上のように, short, long board共に大きくて持ち 運びが困難であるため, surferは車で移動することが多 い. そのため, 広い駐車スペースがある surf spotに surferが集まりやすい. また, 駐車スペースがないsurf spotの中には, surferによる違法駐車などで地元住民と 問題が起きている所もある.
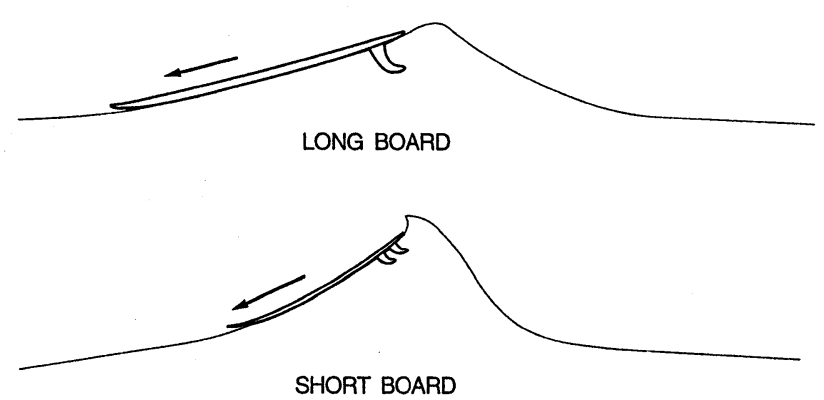

図 -2 Long board と short board の take-off の違い

\section{Surf-riding に適した波浪, 海岸地形および 気象の条件}

Surf-ridingにとって最も重要な要素は波である.あ る海岸がsurf spotとなるためには, surf-ridingに適し た波が立ちやすくなければならないため, 海岸地形条件 が重要になる.ここでは, いかなる条件を満たした波が surf-ridingに適しているのか, さらにそのような波が 立つために海岸地形が満たすべき条件を考察する.一般 に, surf-ridingに適しているか否は, 波高・周期, 砕波 形式などから判断されているが, これでは適切な評価が できない，そこで本研究では，研波の継続時間を間接的 に表す peeling の状沉と, 波面の状態の 2 要素を付け加 える.

（1）波高 ·周期

Surf-ridingは波のエネルギーを利用して波面上をす ベるため, ある程度の波高がなければsurf-ridingはで きない. Long board なら最低限 $40 \sim 50 \mathrm{~cm}$, short boardなら50〜60 cm以上の有義波高が必要となる. ま たsurferが好む波高は，使うboardの種類や個人の技術 レベルによっても異なる ${ }^{5)}$. 全体的にかなり高い波高が 好まれ，上級者ほど高波高を好む傾向がある.

Getting-out の際に, surfer は砕波のエネルギーに よって岸に押し戻されるのを回避するため, 砕波後の白 波が来ると水面下に潜ってくぐり抜ける.これを dolphin-throughというが,これは体力的, 時間的な口 スが大きい. 長い周期の波の方が dolphin-through の 回数が減り, getting-outの際の体力的, 時間的なロス が少なくて済む. さらに, 長い周期の波は水深が浅く なったときの波高の増幅率が大きいためsurf-ridingに 適する.

（2）砕波形式

研波形式は崩れ波, 巻き波, 砕け寄せ波の3つに分類 されるが, このうちsurf-riding では崩れ波または巻き 波が好まれる. 砕波形式は海底勾配と波形勾配によって 決まるが, 海底勾配が全く一様な海岸は存在しないの で，どの程度の海底勾配がsurf-riding に適しているの かは一概には決められない. そこで実際にsurf-riding が行われている海岸の海底地形を調べると, 図 -3 に示
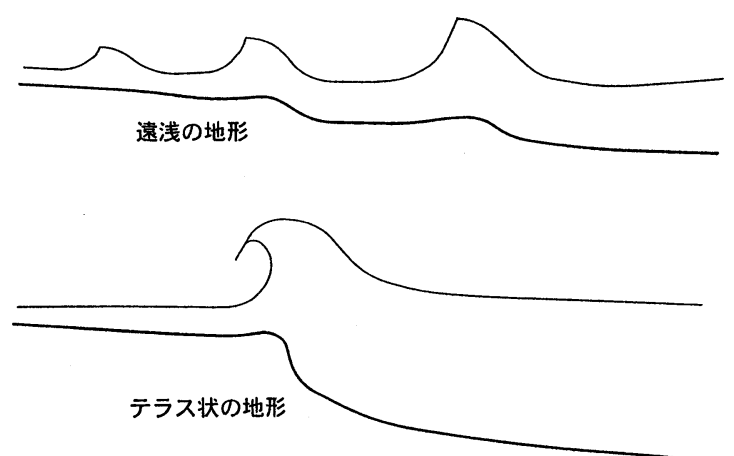

図-3 Surf-riding が行われている海底の断面図 
すように、ほとんどが緩勾配またはテラス状のいず的か の地形である. 例えば, 遠浅の海浜, 河口テラス, 岩礁, サンゴ礁のリーフエッジなどがこれに相当する.

\section{（3） Peelingの状況}

Surf-ridingは砕波点付近でしか行えないので，砕波 継続時間が長い波が良い.つまり, surf-ridingには写真 -5 のように砕波点が徐々に移動していく（写真では右 から左）波が適していて, 写真-6のように波峰線上の全 ての点で一度に崩れる波は適さない.このような砕波継 続時間の長い波（長い peeling距離となる波）が立つの

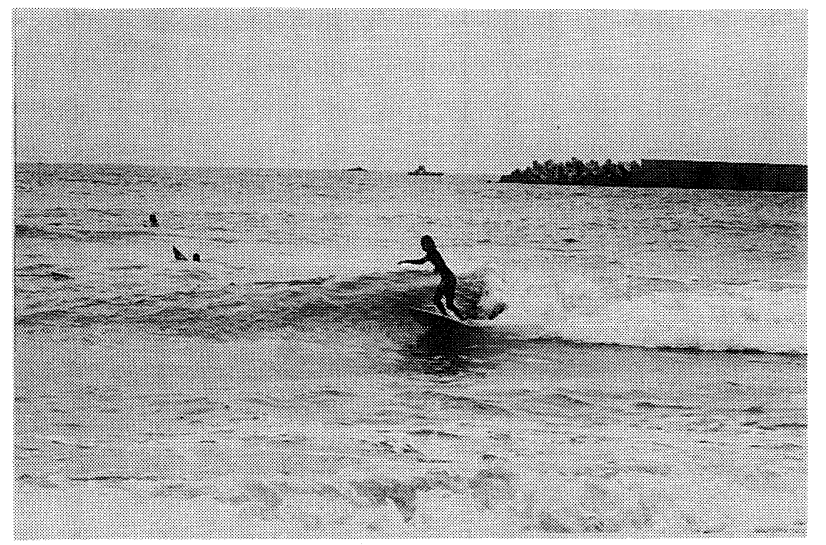

写真 -5 砕波点が徐々に移動していく波 （千葉県鴨川; 1998 年 9 月 12 日撮影)

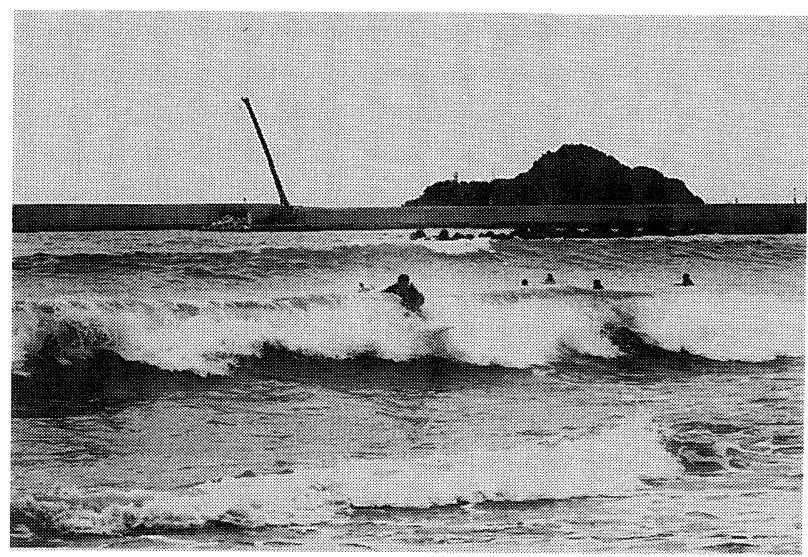

写真 -6 波峰線上の全ての点で同時に崩れる波 （千葉県鴨川; 1998 年 9 月 12 日撮影）

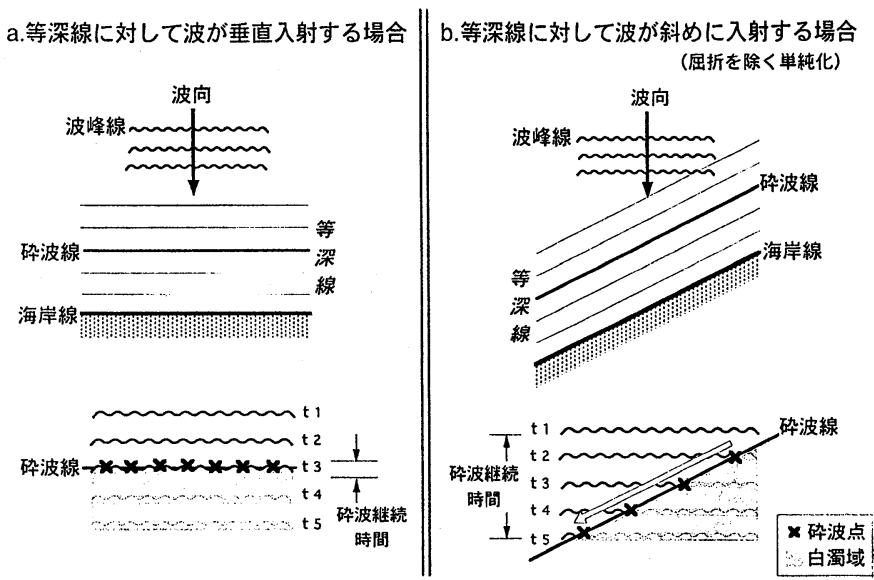

図 -4 等深線に対して波が垂直入射する場合と 斜めに入射する場合の砕波継続時間 は，図-4aのように平行等深線に対して波が直角入射す る場合ではなく，図-4bのように等深線に対して波が斜 めに入射するとき, あるいは波高が沿岸方向分布を有す る場合である．これらが起こりやすい海岸地形は，海岸 から沖に向かって突出した地形, または波を遮蔽する地 形である．波を遮蔽する地形があれば，その遮蔽域では 回折によって波高が沿岸方向分布を有するようになる. 実際，このような地形にあてはまるのは岬，半島，河口 テラスなどの自然地形，あるいは突堤，防波堤，離岸堤 などの人工構造物周辺である.

\section{（4）波面の状態}

上記3条件が満たされたとしても，砕波点付近で強い 風が吹いていると波面が乱されて surf-ridingに適さな くなる. 写真-7, 8はいずれも九十九里浜の片貝新漁港 東岸から南東方向に向けて写したものであるが，写真一 7の撮影時はほぼ無風であったのに対し，写真-8の撮影 時は強い onshoreの風が吹いていた．写真-7では風に よって波面が乱されることなくきれいに砕波している. 一方, 写真-8 では強い onshore の風に波面を乱され, surf-ridingがほとんど不可能になっている.このよう にsurf-ridingには，風の影響をほとんど受けない無風 あるいは弱いoffshoreの風が良いとされるが, 強風時で も，風を遮蔽あるいは風域を分断する地形があれば surf-ridingに適した波が立ちやすくなる.実際に，背後

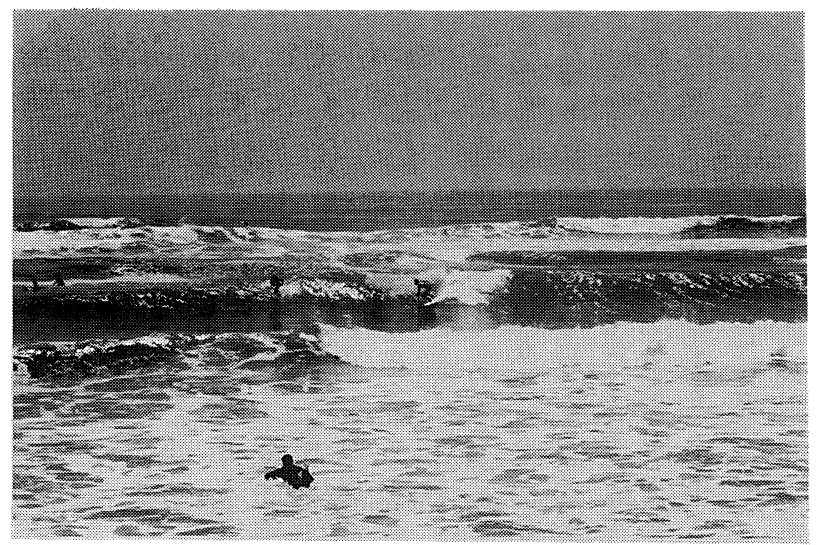

写真 -7 風の影響を受けていない波 (千葉県片貝;1998 年6 月 4 日撮影)

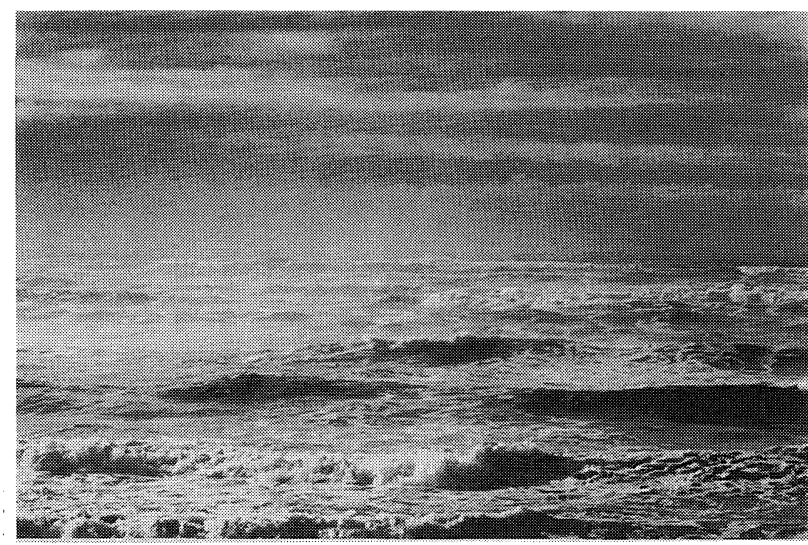

写真-8 風によって波面を乱された波 (千葉県片貝; 1998 年 7 月 23 日撮影) 
表-1 Surf-riding に適した波と海岸地形

\begin{tabular}{|c|c|c|c|}
\hline 波の要素 & 波が満たすべき条件 & 海岸地形が満たすべき条件 & 実際に当てはまる海岸 \\
\hline 波高・周期 & ある程度、波高が高く周期の長い波 & フェッチが大きい場所 & 外洋に直接面した海岸 \\
\hline 碎波形式 & 崩れ波または巻き波 & 緩勾配またはテラス状の地形 & $\begin{array}{l}\text { 遠浅の海浜, 河ロテラス, 岩礁, } \\
\text { サンココ礁 (リーフエッジ) など }\end{array}$ \\
\hline Peelingの状況 & \begin{tabular}{|l} 
研波継続時間の長い波 \\
\end{tabular} & $\begin{array}{l}\text { 海岸から沖に向かって突出した地形 } \\
\text { または波を遮蔽する地形 }\end{array}$ & \begin{tabular}{|l} 
自然地形 : 岬, 河口テラスなど \\
人工構造物 : 突堤,, 防波堤, 離岸堤など
\end{tabular} \\
\hline 波面の状態 & 波面が滑らかな波 & $\begin{array}{l}\text { 風を遮蔽、あるいは風域を分断する } \\
\text { 地形 }\end{array}$ & $\begin{array}{l}\text { 自然地形 : 湾, 背後に山がある海岸など } \\
\text { 人工構造物 : 防波堤など }\end{array}$ \\
\hline
\end{tabular}

に風を遮蔽する山などがある海岸, また湾内や防波堤 の遮蔽域などは比較的風の影響受けにくく，波面がき れいなことが多い. 以上の4条件は表-1に要約される.

\section{4. 空中写真判読に基づく surf spot の変遷 調查 - 鴨川市前原海岸の例 -}

筆者ら ${ }^{6)}$ は, 空中写真を用いて砕波継続 (peeling) 状 況を調查し, surf-ridingに適した波が崩れた後には三 角形状の白濁域が残り，適さない波が崩れた後には帯 状の白濁域が残されることを示し，空中写真からsurfridingの適性調查が可能なことを明らかにした.そして 実際に，九十九里浜の片貝漁港周辺での実例を示した. 本吥究では, この手法により surf spotの変遷調查を 行った. 具体例として図-5に示すように, 房総半島先端 部に位置し，太平洋に面した千葉県鴨川市の前原海岸 を選んだ. 前原海岸は, 延長約 $3.9 \mathrm{~km}$ のポケットビーチ の南西側に位置する長さ $1.2 \mathrm{~km}$ の砂浜海岸であり, わ が国で最も早くから surf-ridingが行われた場所の一つ である. 写真-9に1974, 1998年の2時期の空中写真を示 す。1974年には南端に流入する加茂川の北側に三角形 状の白濁域が3つ観察される．この場所は，当時「赤堤 ポイント」と呼ばれたsurf-ridingに適した場所であっ た.ここは，ポケットビーチの湾入形状と同時に，南端 の沖合の岩礁によって波が屈折して砕波することに よってsurf-ridingに適した波が発生していた。しかし 1998年の空中写真では,「赤堤ポイント」に鴨川フィッ シャリーナが，その北側には離岸堤が施設が建設され, surf-ridingに適した場所が消失したことが分かる.そ して, これは地元のsurferの証言とも一致している.

\section{5. まとめ}

本研究では, surf-ridingの各種条件, およびルールに ついてまず整理した.また, surf-ridingに適した波が崩 れた後には三角形状の白濁域が残ることから, 空中写 真からsurf-ridingの適性調査が可能なことを削報6）で 明らかにした. そして, この手法を鴨川市の前原海岸に 適用したところ, surf spotの消失状況が明らかになり, この手法は今後も各地でのsurf spotの変遷調查に利用

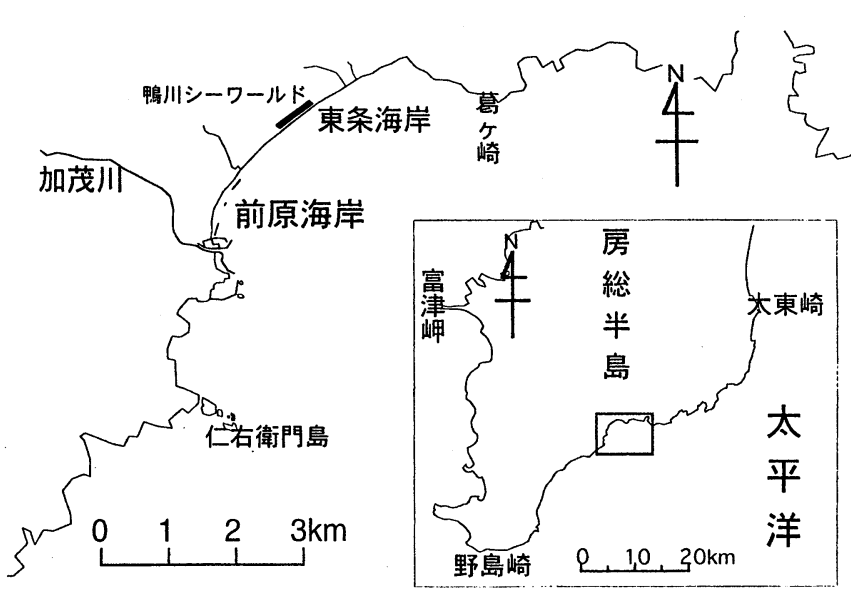

図 -5 千葉県鴨川市前原海岸の位置図
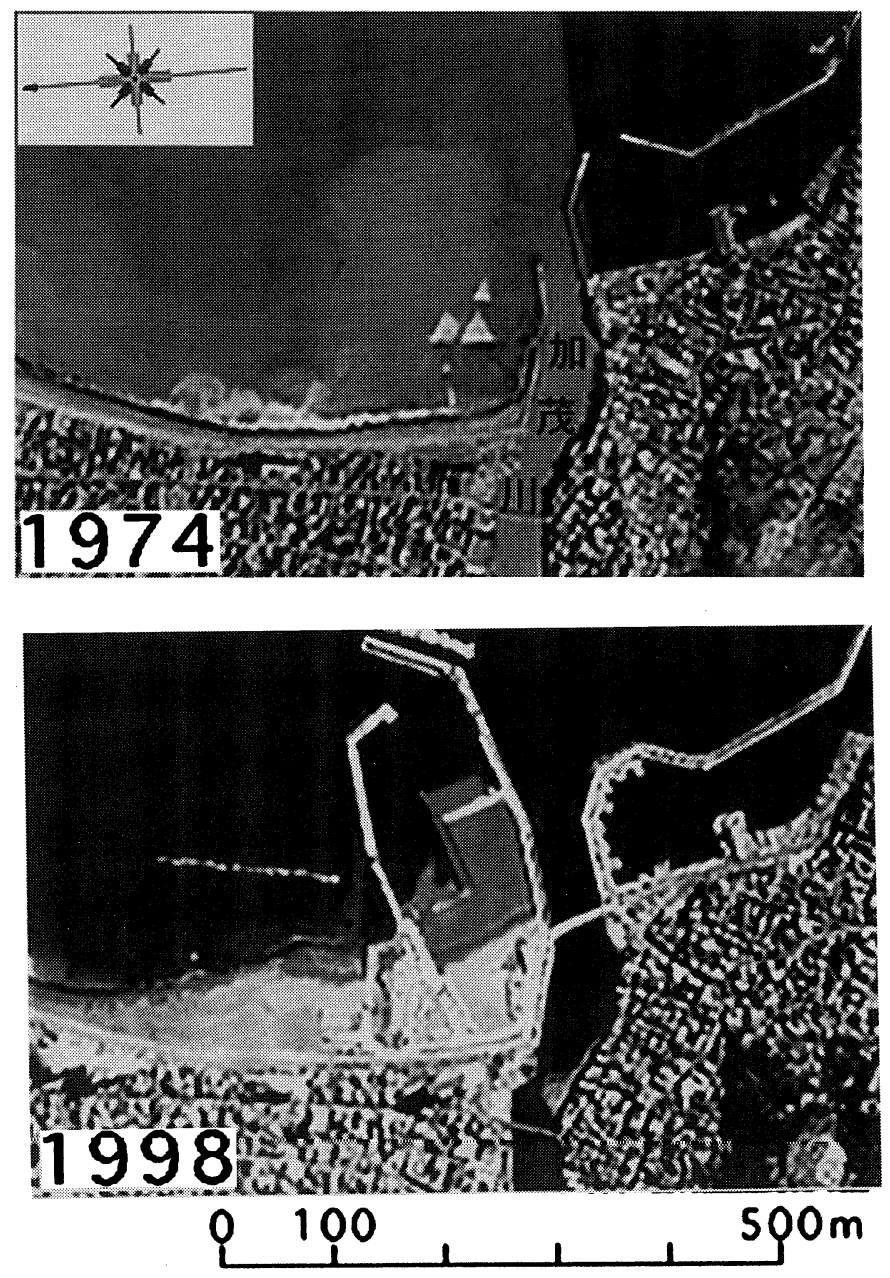

写真 -9 鴨川市の前原海岸の空中写真 
可能であることがわかった.

前報) と今回の調查によって, 海岸人工構造物の建設 はsurf spotの形成・消失どちらにも㗢き得ることがわ かった. 今後, surf spot付近の海岸整備に当たっては, surf-riding という海岸利用の一つの形態に与える影響 にも十分配慮することが望まれる。

謝辞 : 本研究は, 筆者の一人 (渡辺) の東京大学教養学 部における卒業論文の一部であり,研究を進めるにあた り, 小河正基助教授をはじめ地学ゼミの方々に貴重な議 論をしていただいた.また, パシフィックコンサルタン ツ（株）の石川仁憲氏と S.F.J. の上田真寿夫氏には, surf-ridingに関する貴重な意見をいただいた。これら の方々に心より謝意を表します。

\section{参考文献}

1) Walker,J.R. , Palme,P.Q. and Kauke,J.K. : Recreational Surfing on Hawaiian Reef, Proc. 14th
Coastal Eng. Conf., pp.2609-2628, 1972.

2) 吉田義明, 中野 晋, 增味康彰, 三井 宏 : サーフィン に適する波と人エリーフの関係, 海洋開発論文集, Vol.7, pp.113 118, 1991.

3) 中野 晋, 吉田義明, 中野孝二, 三井 宏 : サーフィン に適するデルタ型リーフ周辺の流れと漂砂，海洋開発論 文集, Vol.9, pp.229-234, 1993.

4) 中野 晋, 三島豊秋, 中野孝二, 三井 宏: サーフィン に適するデルタ型リーフ周辺の波浪特性, 海岸工学論文 集, 第 41 巻, pp.721-725, 1994.

5) 石川仁憲, 酒匂敏次 : サーフゲレンデの特性とゲレンデ 計画要件に関する研究, 海洋開発論文集, Vol.13, pp.171-176, 1997.

6) 渡辺宗介, 清野聡子, 宇多高明, 芹沢真澄, 三波俊郎, 古池 鋼：防波堤の建設に起因するサーフスポットの形 成機構, 海岸工学論文集, 第 46 巻, pp.1271-1275, 1999. 